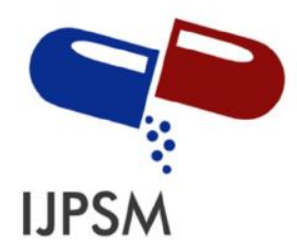

Melvi Resna et al, Int. Journal of Pharmaceutical Sciences and Medicine (IJPSM),

Vol.6 Issue. 8, August- 2021, pg. 152-160

ISSN: 2519-9889

Impact Factor: 3.426

\title{
Phytochemical and Antiinflammatory Properties of Etlingera elatior (Jack) RM Sm.: A Review
}

\author{
Melvi Resna; Fitra Fauziah; Ifora Ifora* \\ Department of Pharmacology and Clinical Pharmacy, School of Pharmaceutical Science (STIFARM) Padang, \\ West Sumatra, Indonesia, 25147 \\ For correspondence: Tel. +6285266031448, Email: iforafo03@gmail.com \\ DOI: 10.47760/ijpsm.2021.v06i08.011
}

\begin{abstract}
Background: Inflammation is part of the biological response that exists in vascular tissue to harmful stimulation. Using medicinal plants can help to treat inflammation. Etlingera elatior (Jack) RM Sm. is one of the medicinal plants.

Objective: The review aims to present information from some research about the phytochemical and antiinflammatory activity of Etlingera elatior (Jack) RM Sm.

Methods: The review provides evidence in the literature for the phytochemical and antiinflammatory activity of Etlingera elatior (Jack) RM Sm. from 2010-2021. The bibliographic databases were used as the primary sources of information (Google Scholar, ScienceDirect, and PubMed). The keywords in this search were "Phytochemical or Phytochemistry" and "Etlingera elatior (Jack) RM Sm. or Nicolaia speciosa Horan" and "Anti-inflammatory or Anti Inflammatory." Five studies were included in this review according to the required criteria.

Results: Phytochemical compounds contained in Etlingera elatior (Jack) RM Sm. dominated by flavonoids, saponins, tannins, terpenoids phenolic, and volatile oils which are widely distributed in leaves, flowers, stems, and rhizomes. Pharmacological studies reported that Etlingera elatior (Jack) RM Sm. shown anti-inflammatory activity by inhibiting regulation of NF- $\mathrm{BB}-\mathrm{p} 65$ expression. It can reduce carrageenan-induced edema in the soles of rat's feet and stabilize erythrocyte membranes.
\end{abstract}

Conclusion: Etlingera elatior (Jack) RM Sm. is the potential medicinal plant to develop as anti-inflammatory therapy.

Keywords: Inflammation, Etlingera elatior, phytochemical

\section{Introduction}

Inflammation is a complex biological response of body tissues to noxious stimuli, such as pathogens, damaged cells, or irritants, and protective responses involving immune cells [1]. Inflammation can be chronic or acute depending on the time and pathological features. Chronic inflammatory disorders such as rheumatoid arthritis, atherosclerosis, asthma, and other inflammations include the development of degenerative diseases [2], [3]. The acute inflammatory phase is characterized by the rapid influx of blood granulocytes by monocytes that mature into inflammatory macrophages, which then proliferate and thereby affect the function of resident tissue macrophages. This process causes acute inflammation such as redness, heat, swelling, and pain [4].

Drugs that are widely used to reduce inflammation are nonsteroidal anti-inflammatory drugs (NSAIDs) because these drugs work by inhibiting the cyclooxygenase 1 and 2 enzymes so that the production of prostaglandins (PGE2) and prostacyclins (PGI2) which are inflammatory mediators that can cause vasoconstriction of blood vessels decreased [5], [6]. The use of nonsteroidal anti-inflammatory drugs 


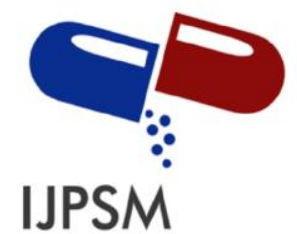

\section{Melvi Resna et al, Int. Journal of Pharmaceutical Sciences and Medicine (IJPSM), Vol.6 Issue. 8, August- 2021, pg. 152-160}

ISSN: 2519-9889

Impact Factor: 3.426

(NSAIDs) usually causes ulceration of the lumen and bleeding of the intestinal mucosa [7], [8]. However, long-term clinical use of nonsteroidal anti-inflammatory drugs (NSAIDs) has shown many side effects such as gastrointestinal and cardiovascular disorders [9], [10]. Natural medicines are increasingly being used in recent years as alternative treatments for inflammation due to their relatively minor side effects [11]. Therefore, there is a strong need for the use of natural products with minimal side effects. Previous studies have shown that different plants have diverse therapeutic activities, including anti-inflammatory activity [12].

Etlingera elatior (Jack) RM Sm. is a spice plant native to Indonesia included in the Zingiberaceae family [13]. E. elatior is a popular plant in Southeast Asia where the inflorescences are traditionally used for culinary and medicinal purposes. In this review, we provide a review of the anti-inflammatory properties of E. elatior.

\section{Data Collection Methods}

The review was searched from scientific literature databases, i.e., Google Scholar, ScienceDirect, and PubMed. We have collected the literature about the phytochemical and antiinflammatory activity of E. elatior from 2010-2021. The keyword was used in searching literature "Phytochemical or Phytochemistry" and "Etlingera elatior or Nicolaia speciosa" and "Anti-inflammatory or Anti Inflammatory." All abstracts and full articles were collected, examined, summarized, and concluded. The most relevant articles were selected for screening and included in this review.

\section{Result and Discussion}

\subsection{Phytochemical of Etlingera elatior}

E. elatior contains several phytochemical compounds summarized in Table 1.

Table 1. Summary on the bioactive compound of Etlingera elatior

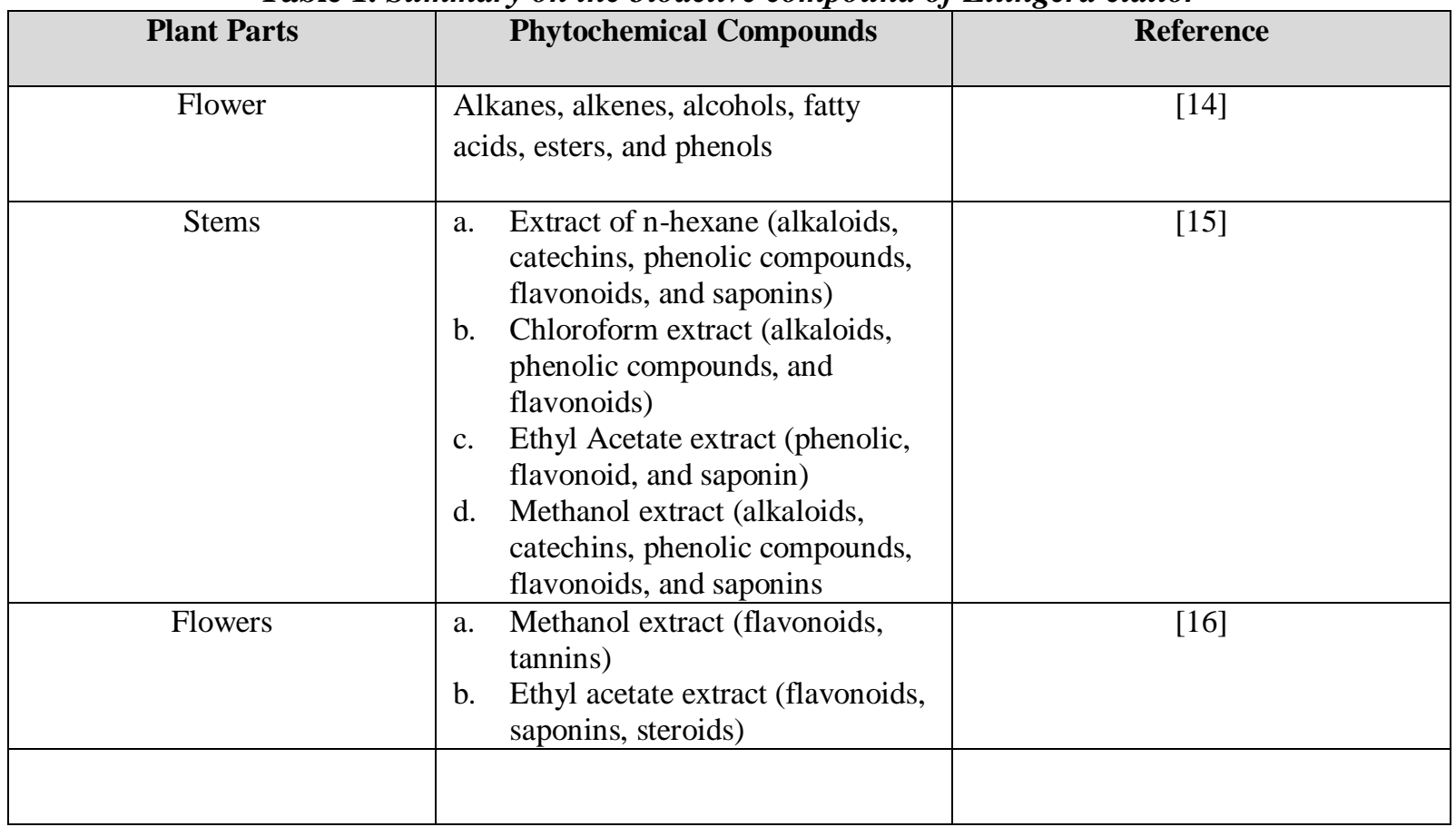




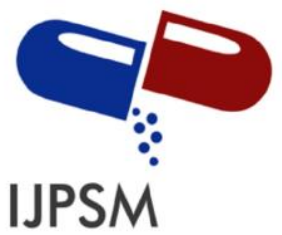

Melvi Resna et al, Int. Journal of Pharmaceutical Sciences and Medicine (IJPSM), Vol.6 Issue. 8, August- 2021, pg. 152-160

ISSN: 2519-9889

Impact Factor: 3.426

\begin{tabular}{|c|l|c|}
\hline Flowers & a. $\begin{array}{l}\text { Phenolic acids (gallic acid, tannic } \\
\text { acid, chlorogenic acid, and } \\
\text { caffeic acid) }\end{array}$ & [17] \\
b. $\begin{array}{l}\text { Flavonoid compounds (quercetin, } \\
\text { apigenin, kaempferol, luteolin, } \\
\text { and myricetin) }\end{array}$ & [18] \\
\hline Leaves and Rhizomes & a. $\begin{array}{l}\text { Rhizome: estragole, methyl } \\
\text { eugenol, beta-phellandrene } \\
\text { beaves: } \beta \text {-thujene, } \alpha \text {-piene, } \\
\text { eucalyptol, linalool }\end{array}$ & \\
\hline
\end{tabular}

Based on the research of Sukandar et al., analysis of chemical components by GCMS chromatography. The results of the GCMS analysis on the water extract of the flower of E. elatior showed that there are at least six main groups of compounds contained in the aqueous extract of E. elatior flower, i.e., alkanes, alkenes, alcohols, fatty acids, esters, and phenols. Three of them were 1-dodecanol, 3-methyl-1-oxo-2-buten-1- $\left(2^{1}, 4^{1}, 5^{1}\right.$ trihydroxyphenyl), and 1-tetradecene [14].

A study conducted by Susilowati et al., stem extraction of E. elatior using n-hexane, chloroform, ethyl acetate, and methanol as solvents. The $\mathrm{n}$-hexane extract contains (alkaloids, catechins, phenolic compounds, flavonoids, and saponins), chloroform extract contains (alkaloids, phenolic compounds, and flavonoids), ethyl acetate extract contains (phenolics, flavonoids, and saponins), methanol extract contains (alkaloids, catechins, compounds phenolics, flavonoids, and saponins). Gas Chromatography-Mass Spectrophotometry (GCMS) was used for the identification of four extracts. N-hexane extract contained dodecanol, palmitic acid, olealdehida, myristyl palmitate, pregn-4-en-3,20-dione, 7,8-epoksi- $\alpha \square$ ionon. Chloroform extract contained dodecanol, decyl acetate, hexadecenal, tridecyl vinyl ester, 14-(2-methyl butyl) bisclo (10,3,0) deca-13-ol. Ethyl acetate extract contained 1,2-ethanediol monoacetate, 1,2-ethanediol diacetate, dodecanal, decyl acetate, cholesteryl chloroformate [15].

Another study conduted by Maimulyanti \& Prihadi, reported that the results of the GCMS analysis of the E. elatior flower showed that the main components were dodecanal, 1-dodecanol, dodecanoic acid, 1hexadecanol, 1-hexadecene, and 17-pentatriacontane. Analysis by GCMS of E. elatior showed that the sample contained volatile compounds in the n-hexane extract. In the E. elatior flower, thirty-nine compounds were successfully identified. The main compound of the E. elatior flower is 1-dodecanol (13.82\%), dodecanal (12.10\%), and 17-pentatriacontane (10.52\%). Other compounds found were dodecanoic acid (10.04\%), 1hexadecene (6.34\%), 1-hexadecanol (4.91\%), 1-heneicosyl formate $(3.71 \%)$, cis vaccenic acid (3.29\%), hexadecanoic acid $(2.31 \%)$, cyclotetradecane $(2.10 \%)$. Preliminary phytochemical screening results were carried out on methanol and ethyl acetate extracts from the samples and showed many phytoconstituents, including tannins, saponins, flavonoids, and steroids. The phytochemical constituents in the methanol extract are flavonoids and tannins. In the ethyl acetate extract, there are flavonoids, saponins, and steroids. These constituents exhibit antioxidant activity in the samples. E. elatior in methanol extract showed strong antioxidant $\left(\mathrm{IC}_{50} 21.14 \mu \mathrm{g} / \mathrm{mL}\right.$ ) compared to ethyl acetate extract $\left(\mathrm{IC}_{50} 68.24 \mu \mathrm{g} / \mathrm{mL}\right)$ [16].

Based on research by Ghasemzadeh et al., showed that E. elatior flower was grown and collected in three different locations in Malaysia, i.e., Kelantan (Northeast), Pahang (Central), and Johor (Southeast). Phenolic acids and flavonoids were isolated and identified using ultra-high-performance liquid chromatography (UHPLC). In this study, four phenolic acids (gallic acid, tannic acid, chlorogenic acid, and caffeic acid) and five flavonoid compounds (quercetin, apigenin, kaempferol, luteolin, and myricetin) were separated and identified from the flower extract of E. elatior, which were collected from three different locations. The results from three different sampling sites showed significant differences. The highest content of gallic acid (129.14 


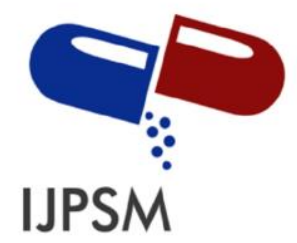

\section{Melvi Resna et al, Int. Journal of Pharmaceutical Sciences and Medicine (IJPSM), Vol.6 Issue. 8, August- 2021, pg. 152-160}

ISSN: 2519-9889

Impact Factor: 3.426

mg/100 g DM, tannic acid (82.66 mg/100 g DM), chlorogenic acid (75.79 mg/100 g DM) was found in flower extracts collected from Kelantan. Chlorogenic acid was not found in the flower extract from Johor. The flavonoid content was significantly different between the flower extracts from the three different locations. Compared with flower extracts from the other two locations, the extracts collected from Kelantan had the highest content of quercetin $(1.95 \mathrm{mg} / \mathrm{g} \mathrm{DM})$, rutin $(1.48 \mathrm{mg} / \mathrm{g} \mathrm{DM})$, kaempferol $(0.56 \mathrm{mg} / \mathrm{g} \mathrm{DM})$, catechins $(89.5 \mathrm{mg} / 100 \mathrm{~g} \mathrm{DM})$, apigenin $(71.88 \mathrm{mg} / 100 \mathrm{~g} \mathrm{DM})$, and myricetin $(35.75 \mathrm{mg} / 100 \mathrm{~g} \mathrm{DM})$. Luteolin at a 48.69 $\mathrm{mg} / 100 \mathrm{~g} \mathrm{DM}$ concentration was detected in former flower tracts from Kelantan but not in extracts from the other two sites. This study shows that an aqueous solvent is more recommended than ethanol to extract phenolic acids, flavonoids, and tannins from E. elatior flower. Secondary metabolite level and medicinal quality of flower E. elatior descending from Southeast to northeast Malaysia. In general, if the three different sampling locations from Northeast (Kelantan) to Southeast (Johor) were compared, the concentration of polyphenols, as well as antioxidant, anticancer, and antibacterial activities, decrease in the following order: Kelantan > Pahang > Johor [17].

A study conduted by Loying et al., reported the results of essential oils were extracted using the hydrodistillation method [19]. The percentage of essential oil yield of fresh leaves and rhizomes were $1.10 \%$ and $0.33 \%$, respectively. GCMS analysis of essential oil of fresh leaves and rhizomes of E. elatior revealed that monoterpenes and sesquiterpenes were more dominant than other compounds. The main compounds were estragole (68\%), methyl eugenol (13.32\%), beta-phellandrene (4.96\%) in rhizome essential oil, while $\beta$-thujene (26.89\%), $\alpha$-pinene (17.08\%), eucalyptol (8.56\%), and linalool (4.64\%) in leaves. A previous study of GCMS analysis of the essential oil of the leaves and rhizomes of this plant showed that the main compounds were myrcene (13.05\%), $\alpha$-humulene (11.80\%), $\beta$-caryophyllene $(10.70 \%), \alpha$-piene $(8.50 \%)$, terpinen-4-ol $(5.00 \%)$, camphene $(18.00 \%)$ and $\beta$-pinene $(16.90 \%)$ [20]. The main chemical compound in essential oil leaf is estragole, an isomer of anethole and methyl eugenol, a member of the alkenyl benzene group consisting of a benzene ring with methoxy an allyl group. Strong antioxidant potential of essential oil of leaves and rhizomes of E. elatior showed $\mathrm{IC}_{50}$ values of 23.07 and $35.83 \mu \mathrm{g} / \mathrm{mL}$ respectively. The percentage of inhibitory values and IC50 showed that essential oil leaf has stronger antioxidant activity than rhizome essential oil [18].

\subsection{Anti-Inflammatory Activity of Etlingera elatior}

Antiinflammatory activity of E. elatior has been done by in vitro and in vivo studies. Five studies were included in this article based on our eligibility criteria. Antiinflammatory activities of E. elatior were summarized in Table 2.

Table 2. Summary on anti-inflammatory activity of Etlingera elatior

\begin{tabular}{|c|l|l|l|l|l|l|}
\hline Plant Part & \multicolumn{1}{|c|}{$\begin{array}{c}\text { Type of } \\
\text { Extract }\end{array}$} & $\begin{array}{l}\text { Dose/Concentr } \\
\text { ation }\end{array}$ & \multicolumn{1}{|c|}{ Method } & Animal/Cell & Pharmacological Activity & Reference \\
\hline Stem & $\begin{array}{l}\text { Extract of n- } \\
\text { hexane, } \\
\text { chloroform, } \\
\text { ethyl } \\
\text { acetate, and } \\
\text { methanol }\end{array}$ & $\begin{array}{l}269.6 ; \quad 999 ; \\
55.32 ; \quad 2396\end{array}$ & $\begin{array}{l}\text { Carrageenan- } \\
\text { induced edema } \\
\text { barriers method } \\
\text { (In Vivo) }\end{array}$ & Wistar Rats & $\begin{array}{l}\text { Ethyl acetate extract can } \\
\text { inhibit the occurrence of } \\
\text { inflammation }\end{array}$ & {$[15]$} \\
\hline Fruit & $\begin{array}{l}\text { Ethanol } \\
\text { Extract }\end{array}$ & $57-84.89 \%$ & $\begin{array}{l}\text { Red blood cell } \\
\text { membrane } \\
\text { stabilization } \\
\text { method } \\
\text { (In Vitro) }\end{array}$ & $\begin{array}{l}\text { Red blood cells } \\
\text { (Erythrocytes) }\end{array}$ & $\begin{array}{l}\text { Ethanol extract of E. elatior } \\
\text { has antiinflammatory } \\
\text { activity by maintaining red } \\
\text { blood cell membranes }\end{array}$ & {$[21]$} \\
\hline
\end{tabular}




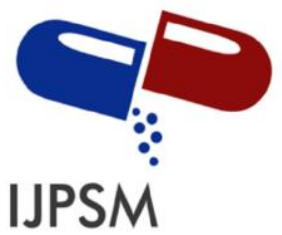

Melvi Resna et al, Int. Journal of Pharmaceutical Sciences and Medicine (IJPSM), Vol.6 Issue. 8, August- 2021, pg. 152-160

ISSN: 2519-9889

Impact Factor: 3.426

\begin{tabular}{|c|l|l|l|l|l|l|}
\hline Flower & $\begin{array}{l}\text { Ethanol } \\
\text { extract }\end{array}$ & $1000 \mathrm{mg} / \mathrm{kg}$ & $\begin{array}{l}\text { Acetic acid- } \\
\text { induced gastric } \\
\text { ulceration } \\
\text { method } \\
\text { (In Vivo) }\end{array}$ & Wistar rat & $\begin{array}{l}\text { Ethanol extract of E. elatior } \\
\text { has antiinflammatory } \\
\text { activity by downregulating } \\
\text { the expression of NF- } \\
\text { kappaB-p65 }\end{array}$ & {$[22]$} \\
\hline Flower & $\begin{array}{l}\text { Gel ethanol } \\
\text { extract }\end{array}$ & $1 \%, 2 \%, 3 \%$ & $\begin{array}{l}\text { Artificial edema } \\
\text { formation by } \\
\text { carrageenan } \\
\text { induction } \\
\text { method } \\
\text { (In Vivo) }\end{array}$ & Female mice & $\begin{array}{l}\text { Ethanol gel flower extract of } \\
\text { E. elatior is effective as } \\
\text { anti-inflammatory }\end{array}$ & {$[23]$} \\
\hline Leaf & $\begin{array}{l}\text { n-Hexane, } \\
\text { ethyl } \\
\text { acetate, } \\
\text { ethanol } \\
\text { extract }\end{array}$ & $\begin{array}{l}50,100,150, \\
200 \mathrm{mg} / \mathrm{kg}\end{array}$ & $\begin{array}{l}\text { Artificial edema } \\
\text { formation by } \\
\text { carrageenan } \\
\text { induction } \\
\text { method } \\
\text { (In Vivo) }\end{array}$ & $\begin{array}{l}\text { Male white rat } \\
\text { Wistar strain }\end{array}$ & $\begin{array}{l}\text { Ethanol, ethyl acetate, and } \\
\text { n-hexane extract of E. } \\
\text { elatior leaves have anti- } \\
\text { inflammatory activity in } \\
\text { reducing edema }\end{array}$ & {$[24]$} \\
\end{tabular}

\section{A. In Vitro Study}

In a study by Fristiohady et al., the method used to test the anti-inflammatory activity of the fruit extract of E. elatior was the method of stabilizing the red blood cell membrane because red blood cells are analogous to the lysosomal membrane. It can maintain the contents of the cytoplasm so that it can inhibit the lysis and release of contents from the cytoplasm. Lysosomes contain inflammatory mediators that can cause tissue damage and inflammatory response [25].

Based on the results study on the fruit extract of E. elatior, the extract has the potential anti-inflammatory. It was evidenced by the value of percent stability of the fruit extract of E. elatior in maintaining the red blood cell membrane. It was $57.75 \%-84.89 \%$, greater than the positive control of $62.61 \%-76.63 \%$. After being given a hypotonic solution and oxidative conditions, the percent value of hemolysis extract was $42.25 \%-15.11 \%$, smaller than the positive control $37.39 \%-23.37 \%$. It showed that the higher the extracted content, the higher its potential as an anti-inflammatory. The concentration of $250 \mathrm{ppm}$ extract has the stability of maintaining red blood cell membranes of $57.75 \%$. The value is smaller than the stability value of diclofenac sodium at a concentration of $250 \mathrm{ppm}$, which is $62.61 \%$. However, the concentration of $500 \mathrm{ppm}$ has the same stability value as sodium diclofenac, with a concentration of $500 \mathrm{ppm} 66.71 \%$. Concentrations of $750,1000,1250$, and $1500 \mathrm{ppm}$ had greater stability values than diclofenac sodium in maintaining red blood cell membranes $74.10 \%, 75.72 \%, 79.87 \%$, and $84.89 \%$. The stability values of diclofenac sodium at $750 \mathrm{ppm}, 1000 \mathrm{ppm}, 1250$ ppm, and $1500 \mathrm{ppm}$ were $71.02 \%, 72.10 \%, 73.94 \%$, and $76.63 \%$. From these data, it can be concluded that the fruit extract of E. elatior can be potentially anti-inflammatory, seen from its very high stability value and low hemolysis value in maintaining red blood cells membranes. The results of the phytochemical screening test found that the ethanol extract of the fruit of E. elatior contains alkaloids, saponins, flavonoids, and terpenoids [21].

Fruit E. elatior contains secondary metabolites in the form of alkaloids, flavonoids, tannins, and terpenoids. Secondary metabolites have an essential role in stabilizing red blood cells and acting as anti-inflammatory agents: flavonoids, tannins, and terpenoids. Based on a previous study, flavonoids can stabilize lysosomal membranes both in vivo and in vitro, while tannins are known to have the ability to bind cations, thereby 


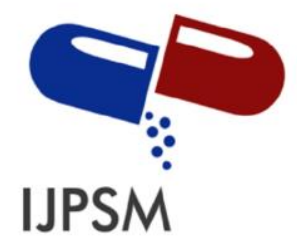

\section{Melvi Resna et al, Int. Journal of Pharmaceutical Sciences and Medicine (IJPSM), Vol.6 Issue. 8, August- 2021, pg. 152-160}

ISSN: 2519-9889

Impact Factor: 3.426

stabilizing erythrocyte membranes and other macromolecules. Flavonoids can also stabilize membranes, and as inhibitors of enzymatic processes during inflammation, flavonoids can inhibit the work of cyclooxygenase and lipoxygenase enzymes in converting arachidonic acid into prostaglandins and leukotrienes, which are inflammatory mediators [26]-[28]. It can be concluded that the ethanol extract of the fruit of E. elatior has the potential to be an anti-inflammatory, seen from its very high stability value and low hemolysis value in maintaining red blood cell membranes [21].

\section{B. In Vivo Study}

Based on research by Susilowati et al., antiinflammatory activity was determined by the method of inhibition of carrageenan-induced edema $(1 \% \mathrm{w} / \mathrm{v}$ in $0.9 \% \mathrm{NaCl})$. For each type of test solution, 48 male Wistar rats were needed, divided into seven groups, each consisting of 6 test animals. The test compound Na-diclofenac was suspended with $0.5 \%$ w/v CMC. Group I was the control group. Groups II, III, IV, V, and VI were the test group given the suspension of the test solution with a dose of 25, 50, 100, 200, and $400 \mathrm{mg}$ extract $/ \mathrm{kg}$ body weight. Group VII was given Na-diclofenac suspension at a dose of $50 \mathrm{mg} / \mathrm{kg}$. Drugs and test compounds were given orally. In the plantar tissue of the rat's right foot, $1 \% \mathrm{w} / \mathrm{v}$ carrageenan suspension was injected in $0.9 \%$ sterile $\mathrm{NaCl}$ as much as $1 \mathrm{~mL}$ subcutaneously [15].

The anti-inflammatory test of the four extracts showed that the n-hexane, chloroform, ethyl acetate, and methanol extracts achieved maximum inflammation inhibition effect after 2.5 hours of carrageenan injection and the four extracts had the optimum dose. At doses higher than the optimum dose, the anti-inflammatory activity decreased. The optimum dose of Na-diclofenac was $13.9 \mathrm{mg} / \mathrm{kg}$, and the edema resistance was $138 \%$. The comparison of the anti-inflammatory power of the four extracts with Na-diclofenac was significant. From the study results, the extracts with the most potent anti-inflammatory activity were methanol extract < chloroform extract < n-hexane extract < ethyl acetate extract. Anti-inflammatory activity (\% edema inhibition) extracts of n-hexane, chloroform, ethyl acetate and methanol were $100 \%$ (dose $269.6 \mathrm{mg} / \mathrm{kg}$ ); $85.99 \%$ (dosage $999 \mathrm{mg} / \mathrm{kg}$ ); $143 \%$ (dosage $55.32 \mathrm{mg} / \mathrm{kg}$ ) and $138 \%(2396 \mathrm{mg} / \mathrm{kg}$ ) and the four extracts had anti-inflammatory activity [15].

A study by Juwita et al., the study on the testing of antiinflammatory activity using the gastric ulcer induction method with acetic acid. Wistar rats were divided into six groups: normal control group, negative control group (gum arabic 2\%), positive control group (quercetin), group 4-6 was treated with E. elatior flower extract doses of 500, 1000, and $2000 \mathrm{mg} / \mathrm{kg}$. In this study, acetic acid was used as an inducer of gastric ulcers. The acetic acid ulcer model was developed in 1969 and proved that by injecting a single dose of acetic acid solution into the gastric mucosal layer of rats, mucosal surface damage would occur 30 minutes after injection.

Furthermore, intraluminal injection of the same acid into the fundal mucosa of mice resulted in a deep, round baroque then developing in the area that had been exposed to the acetic acid solution. NF- $\mathrm{B}$ was activated by acetic acid induction. Acetic acid induction causes local inflammation, increases inflammatory cytokines, reactive oxygen species, and cell damage. Gastric ulcers due to acetic acid also show an increase in TNF- $\alpha$ and IL-1 $\beta$, which causes activation of the NF-kB pathway in the gastric mucosa. It was exacerbated by decreased antioxidant activity such as glutathione, superoxide dismutase (SOD), and catalase activity. Previous studies showed that acetic acid activates the NF-kappaB inflammatory signaling pathway due to stimulation by proinflammatory cytokines such as TNF- $\alpha$ and IL-1 $\beta$ with their receptors [22].

This study also showed that the flower of E. elatior could downregulate NF- $\kappa$ B-p65 expression. Under normal conditions, NF- $\kappa \mathrm{B}$ attaches to I $\kappa \mathrm{B}$ in the cytoplasm. When pathogens or proinflammatory cytokines activate the signaling pathway, the complex was degraded, and released NF- $\kappa \mathrm{B}$ was translocated to the nucleus. Transcription begins when NF- $\mathrm{BB}-\mathrm{p} 65 / \mathrm{p} 50$ interacts with specific DNA in the promoter area of the responsive gene and ultimately regulates gene transcription. The inflammatory process can be inactivated by inhibiting the translocation of NF- $\mathrm{BB}-\mathrm{P} 65$ from the cytoplasm to the nucleus. It can be concluded that the ethanol extract of 


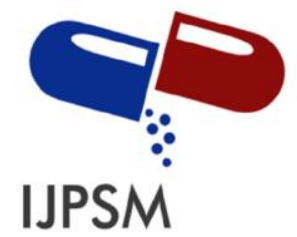

\section{Melvi Resna et al, Int. Journal of Pharmaceutical Sciences and Medicine (IJPSM), Vol.6 Issue. 8, August- 2021, pg. 152-160}

ISSN: 2519-9889

Impact Factor: 3.426

E. elatior flower has anti-inflammatory activity in inhibiting the pathogenesis of gastric ulceration by downregulating the expression of NF- $\mathrm{BB}-\mathrm{p} 65$ in the gastric fundus induced by acetic acid in gastric ulcers of Wistar rats [22].

Carrageenan is a hydrocolloid compound consisting of sodium, potassium sulfate, potassium ester, and magnesium. Carrageenan plays a role in the formation of edema. Carrageenan is a foreign substance which when it enters the body, will stimulate the release of inflammatory mediators such as histamine, causing inflammation due to the body's antibodies reacting to these antigens to counter their effects [29]. At the time of the release of inflammatory mediators, edema occurs and lasts several hours. Inflammation-induced by carrageenan was characterized by increased pain, swelling, and prostaglandin synthesis 4-5 times. Edema caused by carrageenan induction persists for 6 hours and gradually decreases within 24 hours [30].

Wardani's study tested the effectiveness of antiinflammatory carried out by using artificial edema formation using carrageenan induction. Twenty-five female mice were divided into five groups: negative control group (given gel base), positive control group (given Voltaren gel), extract group 1\%, 2\%, and 3\% (given flower extract gel of E. elatior. The mouse's left foot was injected with $0.1 \mathrm{ml}$ of $1 \%$ carrageenan solution in the intraplantar area. Measurement of antiinflammatory effectiveness was carried out by looking at the flower extract gel of E. elatior to reduce the volume of rat paw edema due to carrageenan induction. Flower extract of E. elatior contains flavonoids, saponins, tannins, and terpenoids. The measurement results showed that the average volume of edema in the negative control group increased until the 6th hour, while in the positive control group, the $1 \%, 2 \%$, and $3 \%$ treatment groups experienced a decrease in edema volume. The statistical analysis using the Mann-Whitney test showed a significant difference between the negative control group and the positive control group; the extract group was $1 \%, 2 \%$, and $3 \%$ with significant values respectively 0.009 ; $0.008 ; 0.009 ; 0.009(\mathrm{p}<0.05)$. It can be concluded that the flower extract gel of E. elatior concentration of $3 \%$ was effective as an antiinflammatory in carrageenan-induced mice compared to other treatment groups in this study [23].

Based on research by Alfanda et al., the method used to test the anti-inflammatory activity was the formation of artificial edema on the soles of the rat's feet by using carrageenan as an edema inductor injected intraplantar. The rat's feet were immersed in a plestismometer. In testing the antiinflammatory activity using six treatment groups, each of which consisted of 5 test animals including positive control (Na-diclofenac), negative control (PGA) and the test dose was 50; 100; 150; and $200 \mathrm{mg} / \mathrm{kg} \mathrm{BW}$ and were given leaf extract of E. elatior orally [24].

Based on the calculation of the percentage of inhibition, it can be seen that the ethanol extract at a dose of 200 $\mathrm{mg} / \mathrm{kg}$ BW showed a better percentage of inhibition. Ethanol, ethyl acetate, and n-hexane extract from leaves of E. elatior have the good antiinflammatory ability in reducing edema of $82.29 \%, 72.70 \%, 67.40 \%$, respectively, while the comparison group (Na-diclofenac) can show a percentage of inhibition of $83.48 \%$. The inhibition of ethanol extract at the dose of $50 \mathrm{mg} / \mathrm{kg} \mathrm{BW}$ was $6.56 \%$, while the ethyl acetate and $\mathrm{n}$-hexane extracts decreased the volume of rat paw edema by $9.17 \%$ and $10.11 \%$, respectively. While a dose of 100 $\mathrm{mg} / \mathrm{kg}$ BW can reduce edema in the ethanol extract, the edema volume percentage is $5.76 \%$, while the ethyl acetate extract has an edema volume of $7.90 \%$, then the n-hexane extract obtained an edema volume of $11.62 \%$.

At a dose of $150 \mathrm{mg} / \mathrm{kg} \mathrm{BW}$, it can reduce the percentage of inflammation from ethanol extract by $4.32 \%$, then ethyl acetate and n-hexane extract can reduce inflammation respectively $7.9 \%, 9.86 \%$. The results at a dose of $200 \mathrm{mg} / \mathrm{kg}$ BW extract of ethanol, ethyl acetate, and n-hexane from the leaves of E. elatior decrease inflammation soles of the rats' feet respectively $4.32 \%, 6.66 \%, 7.95 \%$. Leaves extract of E. elatior showed that 


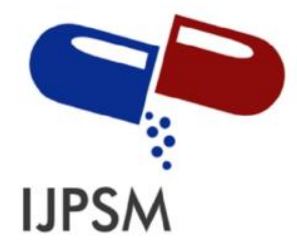

\section{Melvi Resna et al, Int. Journal of Pharmaceutical Sciences and Medicine (IJPSM), Vol.6 Issue. 8, August- 2021, pg. 152-160}

ISSN: 2519-9889

Impact Factor: 3.426

it could reduce inflammation. Phytochemical screening showed that the extracts of ethanol, ethyl acetate, and n-hexane from the leaves of E. elatior contain phenolic compounds, which inhibit inflammation [24].

\section{Conclusion}

The review was confirmed the phytochemical and anti-inflammatory activity in vitro and in vivo of E. elatior. E. elatior phytochemical compounds were dominated by flavonoids, saponins, tannins, terpenoids, phenolic, volatile oils. The pharmacological study reported the inflammatory activity of E. elatior, which inhibits the occurrence of inflammation, reduces edema, maintains erythrocyte membranes, and downregulates expression of NF- $\mathrm{BB}-\mathrm{p} 65$.

\section{ACKNOWLEDGEMENTS}

The study was supported by the Department of Pharmacology and Clinical Pharmacy, School of Pharmaceutical Science Padang (STIFARM Padang).

\section{References}

[1] S. Wahjuni, I. W. Wita, and I. N. M. Astawa, "Anti-Inflammatory Effect of Red Piper Crocatum Leaves Extract Decrease TNF- $\alpha$ and IL-6 Levels in Wistar Rat with Atherosclerosis," Bali Med. J., vol. 5, no. 2, p. 51, 2016, doi: 10.15562/bmj.v5i2.210.

[2] J. N. Fullerton and D. W. Gilroy, "Resolution of Inflammation: A new therapeutic frontier," Nat. Rev. Drug Discov., vol. 15, no. 8, pp. 551-567, 2016, doi: 10.1038/nrd.2016.39.

[3] M. Sajid et al., "Investigations on Anti-Inflammatory and Analgesic Activities of Alnus nitida Spach (Endl). stem bark in Sprague Dawley Rats," J. Ethnopharmacol., vol. 198, pp. 407-416, 2017, doi: 10.1016/j.jep.2017.01.041.

[4] E. Ricciotti and G. A. Fitzgerald, "Prostaglandins and Inflammation," Arterioscler. Thromb. Vasc. Biol., vol. 31, no. 5, pp. 986-1000, 2011, doi: 10.1161/ATVBAHA.110.207449.

[5] H. Agarwal, A. Nakara, and V. K. Shanmugam, "Anti-Inflammatory Mechanism of Various Metal and Metal Oxide Nanoparticles Synthesized Using Plant Extracts: A Review," Biomed. Pharmacother., vol. 109, no. November 2018, pp. 2561-2572, 2019, doi: 10.1016/j.biopha.2018.11.116.

[6] K. Idacahyati, T. Nofianti, G. A. Aswa, and M. Nurfatwa, "Hubungan Tingkat Kejadian Efek Samping Antiinflamasi Non Steroid dengan Usia dan Jenis Kelamin,” J. Farm. Dan Ilmu Kefarmasian Indones., vol. 6, no. 2, p. 56, 2020, doi: 10.20473/jfiki.v6i22019.56-61.

[7] C. Sostres, C. J. Gargallo, and A. Lanas, "Nonsteroidal Anti-Inflammatory Drugs and Upper and Lower Gastrointestinal Mucosal Damage," Arthritis Res. Ther., vol. 15, no. SUPPL 3, pp. 1-8, 2013, doi: $10.1186 /$ ar4175.

[8] J. L. Wallace et al., "Proton pump inhibitors exacerbate NSAID-induced small intestinal injury by inducing dysbiosis," Gastroenterology, vol. 141, no. 4, pp. 1314-1322.e5, 2011, doi: 10.1053/j.gastro.2011.06.075.

[9] S. Harirforoosh, W. Asghar, and F. Jamali, "Adverse Effects of Nonsteroidal Antiinflammatory Drugs: An update of gastrointestinal, cardiovascular and renal complications," J. Pharm. Pharm. Sci., vol. 16, no. 5, pp. 821-847, 2013, doi: 10.18433/j3vw2f.

[10] R. Niranjan, R. Manik, A. K. Srivastava, G. Palit, and S. M. Natu, "Cardiovascular Side Effect Remotely Related to NSAIDs: A comparative experimental study on albino rats," J. Anat. Soc. India, vol. 60, no. 2, pp. 155-159, 2011, doi: 10.1016/S0003-2778(11)80016-X.

[11] S. M. Jachak, R. Gautam, C. Selvam, H. Madhan, A. Srivastava, and T. Khan, "Anti-inflammatory, cyclooxygenase inhibitory and antioxidant activities of standardized extracts of Tridax procumbens L.," Fitoterapia, vol. 82, no. 2, pp. 173-177, 2011, doi: 10.1016/j.fitote.2010.08.016.

[12] M. Arif, I. Ifora, Y. Srangenge, and F. Fauziah, "Potential Anti-Inflammatory Effects of Jatropha curcas L .: A Review," vol. 5, pp. 11-16, 2020.

[13] F. Malik, A. Ningsi, M. Bafadal, D. N. Saktiani, and W. Wahyuni, "Uji Efek Antipiretik Ekstrak Etanol Buah Wualae (Etlingera elatior (Jack) R.M. Smith) Terhadap Mencit Jantan (Mus musculus L.) Galur Balb/C," Pharmauho J. Farm. Sains, dan Kesehat., vol. 4, no. 1, pp. 11-13, 2018, doi: 10.33772/pharmauho.v4i1.4622.

[14] D. Sukandar, N. Radiastuti, I. Jayanegara, and A. Hudaya, "Karakterisasi Senyawa Aktif Antibakteri Ekstrak Air 


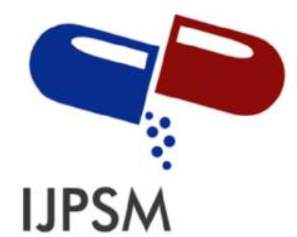

\section{Melvi Resna et al, Int. Journal of Pharmaceutical Sciences and Medicine (IJPSM), Vol.6 Issue. 8, August- 2021, pg. 152-160}

Bunga Kecombrang (Etlingera elatior) Sebagai Bahan Pangan Fungsional,” J. Kim. Val., vol. 2, no. 1, 2010, doi: 10.15408/jkv.v2i1.232.

[15] S. S. Susilowati, S. Martono, S. Riyanto, and E. A. Nugroho, “Aktivitas Analgetika dan Anti-inflamasi Ekstrak Batang Combrang ( Nicolaia speciosa Horan ),” Maj. Farm. Indones., vol. 22, no. 2, pp. 115-119, 2011.

[16] A. Maimulyanti and A. R. Prihadi, "Chemical composition, phytochemical and antioxidant activity from extract of Etlingera elatior flower from Indonesia," J. Pharmacogn. Phytochem., vol. 3, no. 6, pp. 233-238, 2015.

[17] A. Ghasemzadeh, H. Z. E. Jaafar, A. Rahmat, and S. Ashkani, "Secondary Metabolites Constituents and Antioxidant, Anticancer and Antibacterial Activities of Etlingera elatior (Jack) R.M.Sm Grown in Different Locations of Malaysia," BMC Complement. Altern. Med., vol. 15, no. 1, pp. 1-10, 2015, doi: 10.1186/s12906-0150838-6.

[18] R. Loying, R. Gogoi, and M. Lal, "Chemical Composition, Biological Activities and Cytotoxic Effects of Volatile Oils Extracted From Leaves and Rhizomes of Etlingera elatior (Jack) R.M. Sm. as a Potential Plant for Industrial value," J. Environ. Biol., vol. 42, no. Maret, pp. 544-551, 2021, doi: http://doi.org/10.22438/jeb/42/2(SI)/SI-284.

[19] N. Sarma, T. Begum, S. K. Pandey, R. Gogoi, S. Munda, and M. Lal, "Chemical Composition of Syzygium cumini (L.) Skeels Leaf Essential Oil with Respect to its Uses from North East Region of India," J. Essent. OilBearing Plants, no. July 2021, pp. 601-607, 2020, doi: 10.1080/0972060X.2020.1796822.

[20] K. C. Wong, Y. Sivasothy, P. L. Boey, H. Osman, and B. Sulaiman, "Essential oils of Etlingera elatior (Jack) R. M. Smith and Etlingera littoralis (Koenig) Giseke,” J. Essent. Oil Res., vol. 22, no. 5, pp. 461-466, 2010, doi: 10.1080/10412905.2010.9700372.

[21] A. Fristiohady, F. Malik, and N. Fariane, "Uji Aktivitas Antiinfl amasi In Vitro Etlingera elatior ( Jack ) R . M . Smith dengan Metode Stabilisasi Membran Sel Darah Merah ( In Vitro Antiinfl ammatory Activity of Etlingera elatior ( Jack ) R . M . Smith by Hrbc Membrane Stabilization Method ),” J. Ilmu Kefarmasian Indones., vol. 18, no. 2,2020

[22] T. Juwita, W. H. P. Pakpahan, I. M. Puspitasari, N. M. Saptarini, and J. Levita, "Anti-Inflammatory Activity of Etlingera elatior (Jack) r.m. smith Flower on Gastric Ulceration-Induced Wistar Rats," Pakistan J. Biol. Sci., vol. 23, no. 9, pp. 1193-1200, 2020, doi: 10.3923/pjbs.2020.1193.1200.

[23] I. G. A. A. K. Wardani, "Efektivitas Gel Ekstrak Bunga Kecombrang (Etlingera elatior) Sebagai Antiinflamasi Terhadap Mencit Yang Diinduksi Karagenan,” J. Ilm. Medicam., vol. 6, no. 1, pp. 66-71, 2020, doi: 10.36733/medicamento.v6i1.808.

[24] D. Alfanda, S. Slamet, and S. Prasojo, "Uji Aktivitas Anti Inflamasi Ekstrak n-Heksan, Etil Asetat dan Etanol Daun Kecombrang (Etlingera Elatior) Pada Tikus Putih Jantan Galur Wistar (Rattus Norvegiucus),” Umpp, vol. 12, no. 1, pp. 1-6, 2021.

[25] S. Sumathi and R. Anuradha, "In Vitro Anti-Inflammatory Acitivty of Flower Extract of Couroupita guianensis Aubl.," Innovare J. Ayurvedic Siences, vol. 4, no. 5, pp. 4-6, 2016.

[26] A. M. Fahruddin, F. Tatengkeng, R. Thamrin, I. E. Riewpassa, M. Klinik, and M. Preklinik, "Efektivitas Antibakteri Ekstrak Buah Patikala (Etlingera elatior (Jack) R.M. S.m) Terhadap Bakteri Enterococcus faecalis," Makassar Dent J, vol. 5, no. 3, pp. 69-75, 2016.

[27] O. Oyedapo, "Red Blood Cell Membrane Stabilizing Potentials of Extracts of Lantana camara and its Fractions," Int. J. Plant Physiol. Biochem., vol. 2, no. October, pp. 46-51, 2010, [Online]. Available: http://www.academicjournals.org/ijppb/PDF/PDF 2010/Oct/Oyedapo et al.pdf.

[28] E. Wiranto, M. A. Wibowo, and P. Ardiningsih, "Aktivitas Antiinflamasi Secara In-Vitro Ekstrak Teripang Butoh Keling (Holothuria leucospilota Brandt) Dari Pulau Lemukutan,” Jkk, vol. 5, no. 1, pp. 52-57, 2016.

[29] J. Necas and L. Bartosikova, "Carrageenan: A review," Vet. Med. (Praha)., vol. 58, no. 4, pp. 187-205, 2013, doi: 10.17221/6758-VETMED.

[30] F. Nuroini and Z. H. Faruq, "Hitung Leukosit pada Inflamasi Kaki Mencit (Mus musculus) Induksi Karagenan dengan Sarang Walet Putih (Collocali fuciphaga)," vol. 11, no. 02, 2018. 